\section{Determining subduction-zone fluid composition using a tourmaline mineral probe}

\section{V.J. van Hinsberg ${ }^{1 *}$, G. Franz ${ }^{2}$, B.J. Wood ${ }^{3}$}

open access

\section{Abstract}

Subduction zones are the sites where crustal materials are recycled into the mantle. In response to increasing pressures and temperatures during this process, hydrated minerals break down and release solute-bearing fluids and, above $\sim 750{ }^{\circ} \mathrm{C}$, form hydrous melts Magmas generated by interaction of these melts and fluids with the mantle have a characteristic arc elemental signature. Here, a zoned refractory tourmaline grain, formed during Alpine subduction and uplift, was used to reconstruct the compositions of the fluids involved in element transfer. The reconstructed compositions confirm that slab-released fluids carry the arc-signature, and suggest that mineral-fluid element partitioning controls their compositions. However, these fluids are calculated to be dilute. To reconcile this with higher element-to-water ratios required for arc magmas, a two-stage arc-magma genesis model is favoured where fluids imprint their compositional signature progressively on a slab mélange

that is subsequently transferred to, and interacts with the mantle to generate arc magmas.

Received 2 September 2016 | Accepted 6 March 2017 | Published 28 March 2017

\section{Introduction}

The principal material fluxes from the surface into the deep Earth take place a subduction zones. Models of terrestrial element cycling hinge on accurate estimates of these fluxes and of the recycling of material by fluids and melts from the dehydrating slab in the "subduction factory" (Tatsumi, 2005). Estimates of element release from the slab, and hence constraints on the net flux through subduction zones, are derived from three main sources; (i) the compositional signatures of arc magmas (e.g., Elliott et al., 1997), which are $\mathrm{Nb}$-Ta depleted and enriched in $\mathrm{Li}, \mathrm{B}, \mathrm{Sr}, \mathrm{Ba}$ and $\mathrm{Pb}$ compared to mid-ocean ridge basalts (MORB);

\footnotetext{
1. Department of Earth and Planetary Sciences, McGill University, Montreal, Quebec, Canada Corresponding author (email: V.J.vanHinsberg@gmx.net)

2. Department of Applied Geosciences, Technical University Berlin, Berlin, Germany

3. Department of Earth Sciences, University of Oxford, United Kingdom
}

(ii) experimentally-determined element partitioning between subduction-zone solids and liquids (e.g., Keppler, 1996; Kessel et al., 2005; Hermann et al., 2006 ; Spandler et al., 2007; Tsay et al. 2017); and (iii) element mass-balance on subducted rock lithologies (e.g., Bebout et al., 1999; Spandler et al., 2003, 2004). Methods (i) and (iii) provide information on mass transfer from subducting lithologies into the region of melt generation, but no detail on element concentrations in fluids and melt, or total fluxes. Moreover, (iii) depends on the presence of accessory phases (see Klimm et al., 2008; Hermann and Rubatto, 2009), as these phases can be the dominant repository of certain trace elements in the bulk rock. This fact makes the method critically dependent on preservation of these phases, as well as their representative sampling in bulk-rock studies. Method (ii) provides concentration information, and flux estimates when combined with models of release of volatiles (e.g., Spandler et al., 2003; Connolly, 2005), but only under model-dependent conditions of temperature, pressure, mineralogy and bulk composition. What is needed is a more direct record of subduction-zone fluid composition.

Here, well-preserved subduction-zone minerals (tourmaline, titanite and phengite) are used to quantitatively reconstruct the compositions of the fluids from which they grew by combining mineral compositions with mineral-fluid element partition coefficients (cf. Keppler, 1996). If D-values are known for the physico-chemical conditions of growth, absolute element concentrations in the fluid result. This approach avoids any assumption of the presence of accessory phases, but rather allows for their presence to be tested. Furthermore, minerals can simultaneously yield $P-T$ conditions and age of growth that can be combined directly with reconstructed fluid compositions into a comprehensive and internally consistent database of the $P-T-X-t$ evolution of a subduction zone.

\section{Tourmaline as a Mineral Probe}

A tourmaline grain from the Tauern Window Eclogite Zone (Austrian Alps) is the principal probe of fluid compositions in this study. The mineral tourmaline has exceptional $P-T$ stability that covers subduction-zone conditions (Fig. S-1); its crystal-chemistry allows it to incorporate a diversity of (trace) elements; and it displays negligible volume-diffusional re-equilibration (e.g., Henry and Dutrow, 1996; van Hinsberg et al., 2011a,b). These features allow tourmaline to record its host environment composition throughout subduction and to preserve it for later interrogation. Tourmaline's presence is dictated by the availability of boron, rather than by $P-T$ conditions. At low grades, B dominantly resides in sheet silicates (Leeman and Sisson, 1996) and is released during prograde metamorphism in discontinuous reactions resulting in punctuated nucleation and growth, and in continuous reactions producing gradual growth. Owing to negligible diffusive re-equilibration, this growth is expressed as growth zones. 

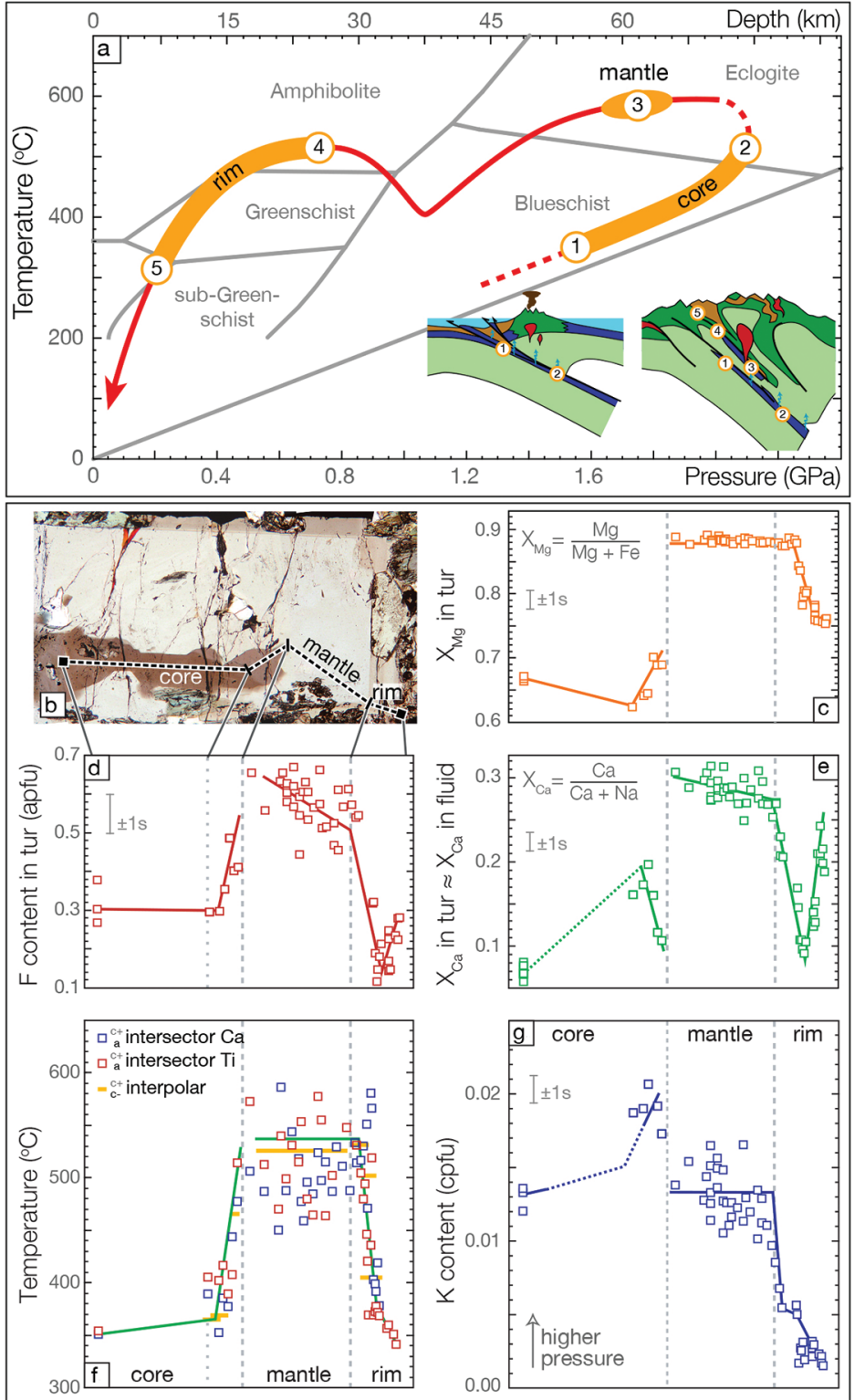

Figure 1 Reading the Tauern tourmaline record. (a) Tauern Eclogite Zone $P-T$ path (Zimmermann et al., 1994) with conditions recorded by tourmaline growth zones shown. Inset cartoon locate these in a schematic subduction-zone cross-section. (b) PPL image of the tourmaline transect. (c) $\mathrm{X}_{\mathrm{Mg}}$ sharply defines the tourmaline growth zones. (d) F-content in tourmaline, $>0.5$ apfu $F$ in the outer core and mantle. (e) $X_{C_{a}}$ of tourmaline, which tracks the $X_{C_{a}}$ in the coexisting fluid (von Goerne et al., 2011). (f) Temperature transect across the tourmaline grain calculated from inter-sector and inter-polar thermometry. (g) Tourmaline K-content which acts as a qualitative barometer. Uncertainties shown are the typical 1s analytical precision.

The Tauern tourmaline grain occurs in a meta-sedimentary retrogressed eclogite that preserves relics of a garnet-omphacite-phengite-titanite eclogite paragenesis, overprinted by an amphibolite-facies amphibole-plagioclaseepidote-carbonate paragenesis (Fig. S-2a). Peak conditions for this unit have been estimated at $630{ }^{\circ} \mathrm{C}$ and $2.5 \mathrm{GPa}$ (e.g., Selverstone et al., 1992; Hoschek, 2007). There is no evidence for partial melting and tourmaline is interpreted to have formed from aqueous fluid throughout its growth history. Tourmaline is a minor accessory phase in these rocks, and is therefore unable to exert control on element concentrations in the fluid. Rather, it acts as a passive recorder of its environment.

Detailed petrographic examination reveals a zoned brown core, a bluegreen mantle, and a strongly zoned outer rim (see the Supplementary Information for more details). Hourglass sector-zoning is present (Fig. S-2b), indicating that growth compositions have been preserved (van Hinsberg et al., 2006). Inter-sector thermometry (van Hinsberg and Schumacher, 2007), combined with qualitative K-barometry and inclusion mineralogy suggests growth of the tourmaline core during prograde subduction and its associated progressive internal B-release, formation of the mantle zone following detachment from the subducting slab from external fluids that were released in deeper slab devolatilisation, and rim growth during retrogression that records the orogenic uplift of the Eclogite Zone (Fig. 1a). This single tourmaline grain thus chronicles the subduction to uplift history, and can provide information on the associated fluids at multiple stages along this path

\section{Tourmaline Composition and Fluid Reconstruction}

Compositions of individual tourmaline growth zones and mineral inclusions were determined by EMP (major elements) and LA-ICP-MS (trace elements). Tourmaline compositions are dominated by the dravite end-member with lesser schorl, uvite and foitite, have variable $X_{C a}$ and $X_{M g}$ and high F contents in core and mantle (Fig. 1, Table S-1). Tourmaline and mineral inclusion compositions constrain growth to be from an acidic aqueous solution with $\mathrm{Na}$ concentrations from 0.45 to $0.75 \mathrm{~mol} \mathrm{~L}^{-1}$, variable $X_{C a}$ and an F-content between 2 and 1400 ppmm (Supplementary Information). Trace element concentrations in tourmaline are low, from tens of ppmm for the LILE to ppbm for the HFSE (Table S-3).

Tourmaline-fluid trace element partition coefficients, required to convert tourmaline compositions to those of their formation fluids, have not been determined experimentally and were therefore estimated (see Supplementary 
Information for details and discussion). As a result, absolute concentrations in the fluid calculated from tourmaline are interpreted to have an associated uncertainty of an order of magnitude. However, element ratios, patterns and the overall elemental signature are robust. A further confirmation of reconstructed fluid compositions is the good agreement between the fluid composition reconstructed from the tourmaline mantle, and the same fluid reconstructed from phengite and titanite inclusions within this growth zone (Tables S-2, S-3).

\section{Controls on Fluid Composition}

The high- $P$ Tauern subduction-zone fluids, reconstructed from tourmaline, phengite and titanite, are dilute aqueous solutions with $<0.75 \mathrm{~mol} \mathrm{~L}^{-1} \mathrm{Na}$ and total trace element concentrations $<500$ ppmm (Fig. 2a). Titanium concentrations suggest saturation in rutile when experimental solubilities (Manning et al., 2008; Rapp et al., 2010; Tsay et al., 2017) are extrapolated to Tauern conditions, consistent with the presence of rutile inclusions in tourmaline's core and mantle. In contrast, fluid REE concentrations are at a median level of only tens of ppbm (Fig. 2a), which is at least 2 orders of magnitude below that required for saturation in the common REE-minerals (Tropper et al., 2011). This level is consistent with REE concentrations in eclogite-fluid experiments with allanitic zoisite (Tsay et al. 2017), where mineral-fluid partitioning, rather than mineral solubility would control REE concentrations.

Fluid compositions reconstructed from well-preserved high- $P$ minerals from the Dora Maira, Syros and New Caledonia palaeo-subduction zones using a similar methodology overlap with those reconstructed for the Tauern Eclogite Zone (Fig. 2a). Absolute concentrations vary by $2-3$ orders of magnitude, but elemental patterns are consistent, and similarly suggest rutile-saturated, but REEphase-undersaturated conditions. Hence, Ti concentrations will be controlled by solubility and are therefore independent of bulk-rock composition and mineral paragenesis until the saturating phase is exhausted (see Klimm et al., 2008) However, for elements controlled by partitioning, such as the REE, differences in slab bulk-rock composition will impart differences in absolute element content of slab-derived fluids. Elemental patterns will persist, assuming no changes in major mineral paragenesis, as is indeed observed (Fig. 2a). Hence, arc magmas will share a characteristic element signature, but absolute concentrations can vary, even on a local scale, depending on the composition and mineralogy of the material that enters the trench.
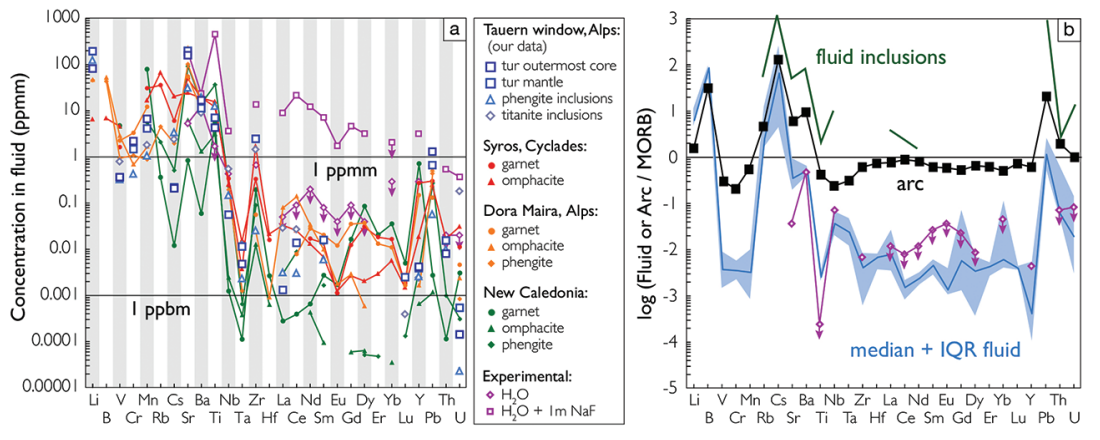

Figure 2 (a) Element concentrations in fluids reconstructed from the Tauern tourmaline outer core and mantle and its mineral inclusions (blue symbols), and eclogite minerals from other subduction-zone terrains show a consistent pattern. (b) MORB-normalised concentrations for average arc magma parallel those of subduction-zone fluids supporting a genetic link. See the Supplementary Information for subduction-zone fluids supporting a genetic link. See given as the Interquartile Range (IQR) and maximum estimates marked with an arrow.

\section{Arc Volcanic Compositional Signature}

To evaluate the resulting fluid compositions, these are compared in a typical arcmagma plot of $\mathrm{Ba} / \mathrm{Th}_{\mathrm{Vs}}$. La/Sm (Fig. 3). La/Sm is controlled by residual garnet in the slab and high values signify a meta-sedimentary input (e.g., Elliott et al., 1997), whereas ${ }^{\mathrm{Ba}} / \mathrm{Th}$ indicates fluid involvement, given the contrasting fluid mobility of Ba and Th (e.g., Keppler, 1996; Elliott et al., 1997). Tourmaline-reconstructed fluids show the high ${ }^{\mathrm{Ba}} / \mathrm{Th}$ at low $\mathrm{La} / \mathrm{Sm}$ signature expected for subduction-zone fluids. This is moreover most distinct for the outermost core and mantle zones, which are interpreted to record the fluid released in slab devolatilisation and that which flushes the subduction channel, respectively. The latter is modified en-route to enrich fluid-compatible Ba over incompatible Th, consistent with models for subduction-zone fluids (Manning, 2004). Fluids reconstructed from phengite and titanite inclusions in the mantle zone are within error of those derived from tourmaline. ${ }^{\mathrm{Ba}} / \mathrm{Th}$ values are lowest for the orogenic uplift part of the history, and suggest that a high $\mathrm{Ba} / \mathrm{Th}$ ratio is characteristic for slab-derived fluids.

Normalised to MORB, the element patterns of the reconstructed fluids, as well as those of fluid inclusions in subduction-zone rocks (e.g., Scambelluri et al. 2001) parallel that of average primitive arc magma; elevated in large-ion lithophile elements while depleted in $\mathrm{V}, \mathrm{Cr}$, and Ti (Fig. 2b). This shows that addition of these slab-derived fluids could confer the arc-characteristic element signature, as was concluded for $\mathrm{Ba} / \mathrm{Th}$. 


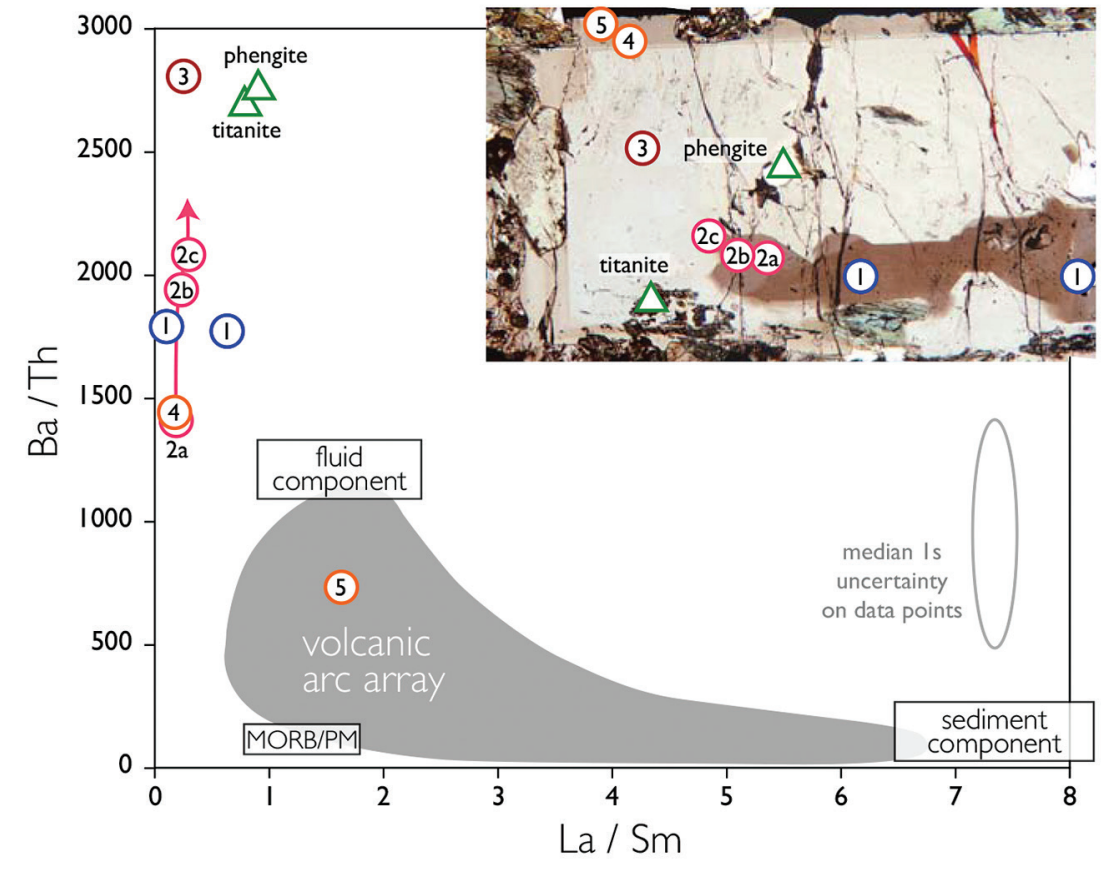

Figure 3 Fluid compositions reconstructed from tourmaline (circles) and its mineral inclusions (triangles), show a consistent, high $\mathrm{Ba} / \mathrm{Th}$ at low La/sm signature. Addition of this fluid to the tism source region can explain the trend to elevated $\mathrm{Ba} / \mathrm{Th}$ compared to mid-ocean ridge basalt (MORB) and primitive mantle (PM).

\section{Material Transfer from the Slab to Mantle}

A fluid to primitive mantle ratio of 10:3 is required to produce the observed range of $\mathrm{Ba} / \mathrm{Th}$ in arc magmas. Such high fluid-to-rock ratios are incompatible with the common conceptual model of arc magmatism where mantle is metasomatised by fluids, and subsequently partially molten, to initiate magmatism. Even when fully hydrated, the mantle cannot accommodate more than $10 \mathrm{wt} . \% \mathrm{H}_{2} \mathrm{O}$. Moreover, arc-magmas are incompatible with the compositional dilution that high fluid-rock ratios impart. MORB-normalised fluid compositions (Fig. 2b) are also incompatible with a model of simple fluid addition to the mantle, with reconstructed concentrations of $\mathrm{Sr}$ and $\mathrm{Ba}$, for example, unable to lead to the observed enrichment in arc magmas. This suggests a decoupling of water and its solutes during arc magma genesis.
Rather than batch fluid transfer to the mantle, we envision channelling of fluids along the slab interface mélange at high fluid-to-rock ratios. The arcsignature is indeed observed in palaeo-subduction mélanges (Marschall and Schumacher, 2012), and the compositional range therein is in agreement with a progressive, and locally variable imprint of this signature by fluids flushing the mélange. Diapirism of this mélange into the mantle can subsequently transfer the compositional signature to the source region of arc magmas (cf. Marschall and Schumacher, 2012 and references therein).

\section{Conclusions}

Reconstruction of subduction-zone fluid compositions from eclogite minerals is a powerful method that allows absolute element concentrations in these fluids to be constrained when partition coefficients for the relevant $P-T-X$ conditions are known. Tourmaline-reconstructed subduction-zone fluid compositions show that fluid-induced selective element release from the subducting slab can imprint the compositional signature characteristic of arc magmas. The compositions of these fluids appear controlled by mineral-fluid partitioning, except for $\mathrm{Ti}$, and subduction-zone fluids are therefore expected to have variable compositions, but share a common elemental signature. Conversion of these fluid compositions into a net element flux in subduction zones is still imprecise, not least because our data indicate that a simple batch model of element transfer from slab to mantle and crust is untenable. Fluids instead likely migrate along the slab interface and progressively redistribute elements as recorded in refractory minerals.

\section{Acknowledgements}

VvH acknowledges financial support from the European Union Seventh Framework Program (FP7/2007-2013) under grant agreement no. 254015. We thank Barbara Dutrow and an anonymous reviewer for their suggestions.

Editor: Helen Williams

\section{Additional Information}

Supplementary Information accompanies this letter at www.geochemicalperspectivesletters.org/article1719

Reprints and permission information are available online at http://www. geochemicalperspectivesletters.org/copyright-and-permissions

Cite this letter as: van Hinsberg, V.J., Franz, G., Wood, B.J. (2017) Determining subduction-zone fluid composition using a tourmaline mineral probe. Geochem. Persp. Let. 3, 160-169. 


\section{References}

Bebout, G., Ryan, J., Leeman, W. Bebout, A. (1999) Fractionation of trace elements by subductionzone metamorphism-effect of convergent-margin thermal evolution. Earth and Planetary Science Letters 171, 63-81.

ConNoLLY, J.A.D. (2005) Computation of phase equilibria by linear programming: A tool for geodynamic modeling and its application to subduction zone decarbonation. Earth and Planetary Science Letters 236, 524-541.

ElliotT, T., Plank, T., Zindler, A., White, W. Bourdon, B. (1997) Element transport from slab to volcanic front at the Mariana arc. Journal of Geophysical Research-Solid Earth 102, 14991-15019.

Henrry D.J., Dutrow, B.L. (1996) Metamorphic tourmaline and its petrologic applications. In: Grew E.S., Anovitz L.M. (Eds.) Boron: Mineralogy, Petrology and Geochemistry. Reviews in Mineralogy 33, 503-557.

HERMANN, J. RUBATTO, D. (2009) Accessory phase control on the trace element signature of sediment melts in subduction zones. Chemical Geology 265, 512-526.

Hermann, J., Spandler, C., HaCK, A., Korsakov, A. (2006) Aqueous fluids and hydrous melts in high-pressure and ultra-high pressure rocks: Implications for element transfer in subduction zones. Lithos 92, 399-417.

HoscheK, G. (2007) Metamorphic peak conditions of eclogites in the Tauern Window, Eastern Alps, Austria: Thermobarometry of the assemblage garnet + omphacite + phengite + kyanite + quartz. Lithos 93, 1-16.

KEPPLER, H. (1996) Constraints from partitioning experiments on the composition of subduction-zone fluids. Nature $380,237-240$

Kessel, R., Schmidt, M.W., Ulmer, P., PettKe, T. (2005) Trace element signature of subductionzone fluids, melts and supercritical liquids at 120-180 km depth. Nature 437, 724-727.

KLIMM, K., BLUNDY, J.D., GREEN, T.H. (2008) Trace element partitioning and accessory phase saturation during $\mathrm{H}_{2} \mathrm{O}$-saturated melting of basalt with implications for subduction zone chemical fluxes. Journal of Petrology 49, 523-553.

LEEMAN, W.P., SISSON, V.B. (1996) Geochemistry of boron and its implications for crustal and mantle processes. Reviews in Mineralogy and Geochemistry 33, 645-707.

MANNING, C.E. (2004) The chemistry of subduction-zone fluids. Earth and Planetary Science Letter $223,1-16$.

Manning, C.E., Wilke, M., Schmidt, C., CAuZid, J. (2008) Rutile solubility in albite- $\mathrm{H}_{2} \mathrm{O}$ and $\mathrm{Na}_{2} \mathrm{Si}_{3} \mathrm{O}_{7}-\mathrm{H}_{2} \mathrm{O}$ at high temperatures and pressures by in-situ synchrotron radiation micro-XRF. Earth and Planetary Science Letters 272, 730-737.

MARSCHALL, H.R., SCHUMACHER, J.C. (2012) Arc magmas sourced from mélange diapirs in subduction zones. Nature Geoscience 5, 862-867.

RAPP, J.F., Klemme, S., ButLeR, I.B., Harley, S.L. (2010) Extremely high solubility of rutile in chloride and fluoride-bearing metamorphic fluids: An experimental investigation. Geology $38,323-326$

Scambelluri, M., Bottazzi, P., Trommsdorff, V., Vannucci, R., Hermann, J., GomezPUGNAIRE, M.T., SANCHEZ-VIZCAINO, V.L. (2001) Incompatible element-rich fluids released by antigorite breakdown in deeply subducted mantle. Earth and Planetary Science Letters 192 $457-470$.

Selverstone, J., Franz, G., Thomas, S., Getty, S. (1992) Fluid variability in 2 GPa eclogites as an indicator of fluid behavior during subduction. Contributions to Mineralogy and Petrology $112,341-357$.

Spandler, C., Hermann, J., Arculus, R., Mavrogenes, J. (2003) Redistribution of trace elements during prograde metamorphism from lawsonite blueschist to eclogite facies; implications for deep subduction-zone processes. Contributions to Mineralogy and Petrology 146, 205-222.
Spandler, C., Hermann, J., Arculus, R., Mavrogenes, J. (2004) Geochemical heterogeneity and element mobility in deeply subducted oceanic crust; insights from high-pressure mafic rocks from New Caledonia. Chemical Geology 206, 21-42.

Spandler, C., Mavrogenes, J., Hermann, J. (2007) Experimental constraints on element mobility from subducted sediments using high-P synthetic fluid/melt inclusions. Chemical Geology 239, $228-249$

TATSUMI, Y. (2005) The subduction factory: How it operates in the evolving Earth. GSA today 15, 4-10.

TropPer, P., MANNING, C.E., HARLOV, D.E. (2011) Solubility of $\mathrm{CePO}_{4}$ monazite and $\mathrm{YPO}_{4}$ xenotime in $\mathrm{H}_{2} \mathrm{O}$ and $\mathrm{H}_{2} \mathrm{O}-\mathrm{NaCl}$ at $800^{\circ} \mathrm{C}$ and $1 \mathrm{GPa}$ : Implications for REE and $\mathrm{Y}$ transport during high-grade metamorphism. Chemical Geology 282, 58-66.

TsaY, A., ZajACZ, Z., Ulmer, P., SANCheZ-VAlle, C. (2017) Mobility of major and trace elements in the eclogite-fluid system and element fluxes upon slab dehydration. Geochimica et Cosmochimica Acta 198, 70-91.

VAN HINSBERG, V.J., SCHUMACHER, J.C. (2007) Intersector element partitioning in tourmaline: potentially powerful single crystal thermometer. Contributions to Mineralogy and Petrology 153, 289-301.

van HinsberG, V.J., Schumacher, J.C., Kearns, S., Mason, P.R.D., FranZ, G. (2006) Hourglass sector zoning in metamorphic tourmaline and resultant major and trace-element fractionation. American Mineralogist 91, 717-728.

van HinsBerg, V.J., HenRY, D.J., Dutrow, B.L. (2011a) Tourmaline as a Petrologic Forensic Mineral: A Unique Recorder of Its Geologic Past. Elements 7, 327-332.

van HinsberG, V.J., HenRY, D.J., MARSChall, H.R. (2011b) Tourmaline: an Ideal Indicator of Its Host Environment. Canadian Mineralogist 49, 1-16.

VON Goerne, G., Franz, G. van HinsberG, V.J. (2011) Experimental determination of Na-Ca distribution between tourmaline and fluid in the system $\mathrm{CaO}-\mathrm{Na}{ }_{2} \mathrm{O}-\mathrm{MgO}-\mathrm{Al}_{2} \mathrm{O}_{3}-\mathrm{SiO}_{2}-$ $\mathrm{B}_{2} \mathrm{O}_{3}-\mathrm{H}_{2} \mathrm{O}$. Canadian Mineralogist 49, 137-152.

ZimmermanN, R., HAMmERSCHMidt, K., FRANZ, G. (1994) Eocene high pressure metamorphism in the Penninic units of the Tauern Window (Eastern Alps): evidence from ${ }^{40} \mathrm{Ar}-{ }^{39} \mathrm{Ar}$ dating and petrological investigations. Contributions to Mineralogy and Petrology 117, 175-186. 